Jurnal Onoma: Pendidikan, Bahasa dan Sastra PBSI FKIP Universitas Cokroaminoto Palopo Volume 6 Nomor 2
ISSN 2443-3667 (print)

ISSN 2715-4564 (online)

\title{
Analisis Faktor Sosial Pemertahanan Bahasa Dentong di Kabupaten Maros
}

\author{
Kasmawati, Fitrawahyudi \\ Universitas Muslim Maros \\ Kasmawati@Umma.ac.id, Fitrawahyudi@Umma.ac.id
}

\begin{abstract}
Abstrak
Penelitian ini bertujuan untuk mengungkap faktor-faktor sosial penggunaan bahasa Dentong melaui indikator sikap bahasa pengguna bahasa, serta untuk mengetahui daya hidup bahasa maka akan dilakukan pengukuran daya hidup bahasa Dentong berdasarkan penggunaan bahasa pada usia dibawah 25 tahun (usia produktif bertahannya bahasa). Metode yang digunakan dalam penelitian ini yakni metode survei, observasi dan wawancara, metode survei menggunakan kuesioner digunakan untuk mengungkap faktor-faktor sosial penggunaan bahasa Dentong, sedangkan metode observasi dan wawancara digunakan untuk memproyeksi daya hidup bahasa Dentong. Analisis data yang digunakan yaitu analisis data secara bertahap melalui kegiatan reduksi data, model data (display data) dan penarikan/verifikasi kesimpulan. Hasil penelitian dapat disimpulkan bahwa pemertahanan bahasa Dentong berada dalam kategori baik, didasari atas persentase penggunaan bahasa pada seluruh kelompok usia sebesar 93\% yang masih menggunakan bahasa Dentong dan penggunaan bahasa Dentong sebagai alat interaksi utama baik dalam komunikasi intrakeluarga, maupun antar keluarga.

Kata kunci: pemertahanan bahasa, daya hidup bahasa, bahasa Dentong
\end{abstract}

\section{Pendahuluan}

Kepunahan bahasa merupakan isu yang makin banyak diperbincangkan oleh para ahli linguistik di dunia. Unesco telah menetapkan tanggal 21 Februari sebagai peringatan hari Bahasa Ibu Internasional. Hal ini didasari atas perenungan terhadap kondisi bahasabahasa daerah di dunia yang telah banyak mengalami kepunahan. Grimes (dalam Ibrahim, 2011), dari jumlah 6.809 bahasa di dunia, terdapat 330 bahasa memiliki lebi dari satu juta penutur, kira-kira 450 bahasa di dunia yang memiliki jumlah penutur yang sangat kecil, telah berusia tua dan condong bergerak menuju ke kepunahan. Saat yang sama, jumlah penutur bahasa-bahasa di dunia hanya berkisar 6.000 orang atau lebih, hanya separuhnya memiliki penutur 6.000 orang atau lebih penutur, dan hanya separuhnya lagi memiliki penutur kurang dari 6.000 orang.

Di Sulawesi Selatan terdapat dua bahasa yang dianggap sebagai bahasa mayoritas di Indonesia. Bahasa tersebut yakni bahasa Bugis dan Makassar. Namun besarnya jumlah populasi penduduk sebagai penutur bahasa tidak menjamin sehatnya kehidupan bahasa daerah. Hasil penelitian Amir (2009) penelitian mengenai pemilihan bahasa pada masyarakat Kabupaten Pangkep menunjukkan bahwa pada semua kelompok usia lebih memilih menggunakan bahasa Indonesia dari pada bahasa daerah, meskipun pada kondisi yang respondenya bilingual/multilingual. Sementara itu, Lukman dan Gusnawaty (2013) mengungkap bahwa bahasa daerah besar di Sulawesi Selatan telah mengalami pergeseran pada wilayah perkotaan dengan jumlah persentase sebesar $52.20 \%$, sedangkan sebanyak $19.15 \%$ pergeseran terjadi di wilayah pedesaan. Hal tersebut menunjukkan bahwa pergeseran bahasa yang terjadi pada bahasa Bugis dan Makassar akibat dari tidak lagi 
Jurnal Onoma: Pendidikan, Bahasa dan Sastra PBSI FKIP Universitas Cokroaminoto Palopo Volume 6 Nomor 2
ISSN 2443-3667 (print)

ISSN 2715-4564 (online)

digunakannya pada usia produktif menandakan bahwa kedua bahasa tersebut berada dalam ancaman kepunahan.

Kabupaten Maros dikategorikan masyarakat multilingual dengan penggunaan bahasa daerah secara berimbang antara bahasa Bugis dan Makassar. Selain memiliki karakteristik tersebut, ditemukan pula bahasa minoritas yang jauh berbeda dengan bahasa Bugis dan Makassar. Masyarakat setempat menyebutnya bahasa Dentong. Pengkajian terhadap bahasa Dentong masih sangat minim ditemukan, utamanya dalam menentukan status kebahasaannya, sebagian ahli menyebutnya sebagai sub dialek dari bahasa Makasar karena secara kekerabatan bahasa Dentong lebih dekat dari bahasa Makassar dibanding bahasa Bugis (Nasrullah, 2016). Namun masyarakat setempat menyebutnya sebagai bahasa tersendiri dan menolak anggapan bahwa bahasa Dentong adalah bagian (lahiran) dari bahasa Bugis atau Makassar, hal ini membuktikan bahwa masyarakat setempat memiliki kebanggan tersendiri terhadap bahasanya.

Bertahannya sebuah bahasa disebabkan oleh sikap pengguna yang positif terhadap bahasa. Jika melihat secara awal kondisi pengguna bahasa Dentong sebagai bahasa minoritas, bahkan hidup di antara pengguna bahasa Bugis yang merupakan bahasa mayoritas bukan hanya di Kabupaten Maros tapi Sulawesi Selatan secara umum, maka seharusnya terjadi pergeseran bahasa pada penggunaan bahasa Dentong, hal ini juga diperkuat karena masyarakat pengguna bahasa Dentong tidak terisolasi dengan masyarakat pengguna bahasa lainnya, sangat jauh berbeda dengan bahasa minoritas yang masih bertahan yang cenderung terisolasi. Sehingga asumsi awal disebutkan bahwa sikap pengguna bahasa Dentong sangat positif terhadap bahasa.

Penelitian ini bertujuan untuk mengungkap faktor-faktor sosial penggunaan bahasa Dentong melaui indikator sikap bahasa pengguna bahasa, serta untuk mengetahui daya hidup Bahasa, maka akan dilakukan pengukuran daya hidup bahasa Dentong berdasarkan penggunaan bahasa pada usia 17-25 tahun (usia produktif bertahannya bahasa).

\section{Kerangka Teori}

Gejala pemertahanan dan pergeseran bahasa merupakan salah satu objek kajian dalam sosiolinguistik. Fenomena bahasa ini dianggap menarik karena sangat identik dengan isu kepunahan bahasa daerah yang semakin marak didiskusikan pada forumforum internasional. Pemertahanan dan pergeseran bahasa erat kaitannya dengan dengan pilihan bahasa dan kedwibahasaan, hal ini berkaitan karena umumnya terjadi pada masyarakat atau individu yang menguasai lebih dari satu bahasa. Selain kedewibahasawan, pergeseran bahasa juga erat dengan masalah penggunaan bahasa oleh seorang penutur bahasa.

Pemertahanan bahasa lebih mengacu kepada sebuah situasi pada masyarakat atau individu masih mencoba untuk menjaga bahasa dengan cara menggunakan bahasanya sebagai pilihan utama dalam berkomunikasi. Sumarsono dan Partana (2004) mengungkapkan bahwa dalam pemertahanan bahasa suatu komunitas secara kolektif menentukan untuk melanjutkan memakai bahasa yang sudah biasa digunakan.

Menurut Sumarsono (dalam Chaer dan Agustina, 2010) dalam laporan penelitiannya mengenai pemertahanan penggunaan bahasa Melayu Loloan di desa Loloan yang termasuk dalam wilayah kota Nagara, Bali (dikutip), ada beberapa faktor yang 
Jurnal Onoma: Pendidikan, Bahasa dan Sastra PBSI FKIP Universitas Cokroaminoto Palopo Volume 6 Nomor 2
ISSN 2443-3667 (print)

ISSN 2715-4564 (online)

menyebabkan bahasa itu dapat bertahan, yaitu: pertama, wilayah pemukiman mereka terkonsentrasi pada satu tempat yang secara geografis agak terpisah dari wilayah pemukiman masyarakat Bali. Kedua, adanya toleransi dari masyarakat mayoritas Bali yang mau menggunakan bahasa Melayu Loloan dalam berinteraksi dengan golongan minoritas Loloan. Ketiga, anggota masyarakat Loloan, mempunyai sikap keislaman yang tidak akomodatif terhadap masyarakat, budaya, dan bahasa Bali. Pandangan seperti ini dan ditambah dengan terkonsentrasinya masyarakat Loloan ini menyebabkan minimnya interaksi fisik antara masyarakat Loloan yang minoritas dan masyarakat Bali yang mayoritas.

Penelitian tentang pemertahanan bahasa telah banyak dilakukan di Indonesia. Budhino (2019) melakukan penelitian yang berjudul Pergeseran dan Pemertahanan Bahasa Jawa di Daerah Transmigrasi di Kota Palangkaraya, penelitian ini merupakan penelitian deskriptif dan kualitatif yang bertujuan untuk keadaan kebahasaan dan mendeskripsikan upaya pemertahanan bahasa Jawa yang dilakukan oleh para responden yang menghuni kawasan transmigrasi di km 38 Kota Palangkaraya. Hasil penelitian menunjukkan ranah memengaruhi pilihan bahasa, terdapat perbedaan rata-rata pilihan bahasa pada ranah dan variabel tertentu yang memunculkan pergeseran bahasa yang memprihatinkan. Selain itu, upaya pemertahanan yang dilakukan oleh para penutur yang tinggal di daerah itu bersifat manasuka, sukarela, tidak terstruktur, dan tidak formal. Akibatnya regenerasi penutur bahasa Jawa tidak berjalan dengan baik dan tidak berkesinambungan.

Hasil penelitian Sahril (2018) dengan judul Pergeseran Bahasa Daerah pada AnakAnak di Kuala Tanjung Sumatra Utara bertujuan untuk menggambarkan kondisi pergeseran Bahasa daerah dikalangan anak-anak di Kuala Tanjung Sumatra Utara. Penelitian ini menggunakan matode deskriptif kuantitatif-kualitatif dengan teknik pengumpulan data observasi, kuesioner, dan wawancara. Hasil penelitian menunjukkan adanya kondisi pergeseran bahasa di kalangan anak-anak di Kuala Tanjung. Pada ranah keluarga dan ranah resmi dan tidak resmi di sekolah menunjukkan dominannya penggunaan bahasa Indonesia, hampir semua jawaban responden menunjukkan kurangnya penggunaan bahasa daerah oleh anak-anak walaupun dari segi sikap responden terhadap penggunaan bahasa daerah cukup mengembirakan. Akan tetapi, tidak memberi pengaruh pada pemertahanan bahasa daerah sehingga disimpulkan telah terjadi pergeseran bahasa..

\section{Metode Penelitian}

Pengumpulan data dalam penelitian ini berbentuk survei penggunaan bahasa Dentong. Selain metode survei melalui penyebaran angket (kuesioner), dalam penelitian ini pula menggunakan metode wawancara dan observasi. Anderson (2010) dalam pelaksanakan survei sosiolinguistik sebaiknya memakai kuesioner, melakukan wawancara dan mengobservasi langsung pemakaian bahasa di daerah sasaran. Kuesioner dimaksudkan untuk mengungkap faktor pemilihan bahasa, wawancara dan observasi untuk mengungkap faktor-faktor sosial pemertahanan bahasa.

Data yang diperoleh pada pegumpulan data berbentuk data penggunaan dan sikap pengguna terhadap bahasa daerah, serta informasi-informasi responden terhadap faktor- 
Jurnal Onoma: Pendidikan, Bahasa dan Sastra PBSI FKIP Universitas Cokroaminoto Palopo Volume 6 Nomor 2
ISSN 2443-3667 (print)

ISSN 2715-4564 (online)

faktor pemilihan bahasa daerah. Selanjutnya dilakukan analisis data yang terbagi atas tiga tahap yakni reduksi data, model data, dan penarikan/verifikasi kesimpulan (Miles dan Huberman, dalam Emzir 2016). Reduksi data merujuk pada proses pemilihan, pemokusan, penyederhanaan, abstraksi dan pentransformasian data mentah yang terjadi dalam catatan-catatan lapangan tertulis. Reduksi adalah suatu bentuk analisis yang mempertajam, memilih, memokuskan, membuang, dan menyusun data. Sedangkan Model data (Display Data) merupakan penguraian, penentuan dan pengelompokan data berdasarkan kesamaan karakteristik data. Adapun penarikan/verifikasi kesimpulan merupakan pemutusan apakah makna data secara jelas, eksplisit dan mendasar yang diistilahkan kesimpulan akhir.

\section{Hasil dan Pembahasan}

Pemertahanan bahasa dapat dinilai dari kebiasaan penggunaan bahasa oleh masyarakat atau individu penutur bahasa pada setiap ranah penggunaan bahasa yang dipilih sebagai alat interaksi. Penggunaan bahasa Denton pada masyarakat tutur Kecamatan Cenrana Kabupaten Maros masih dapat digolongkan dengan tingkat pemertahanan yang tinggi, hal ini dapat dilihat dari penggunaan bahasa Dentong pada variabel usia dan pendidikan penutur, serta penggunaan bahasa pada ranah keluarga, tetangga, pendidikan dan pemerintahan.

Usia penutur merupakan variabel sosial yang sangat dipertimbangkan dalam membuat proyeksi terhadap ancaman kepunahan suatu bahasa. Bahasa yang dianggap masih aman dari ancaman kepunahan (safe languages) ketika bahasa tersebut masih dipelajari dan digunakan dikalangan usia tua hingga anak-anak oleh penutur aslinya (native speaker) sebagai bahasa Ibu (Ibrahim: 2011), begitu pula sebaliknya, apabila penutur tidak lagi menggunakan bahasa daerahnya diusia produktif seperti diusia remaja menjelang dewasa, maka bahasa tersebut dapat digolongkan menuju kepunahan (endangered languages).

Penggunaan bahasa Dentong oleh penutur di Kabupaten Maros masih menunjukkan kondisi yang positif bagi daya hidup bahasa Dentong. Hal ini ditunjukkan dari prilaku penutur dalam penggunaan bahasa daerahnya masih tinggi, bahkan pada klasifikasi usia responden tidak terlihat adanya pembeda terhadap penggunaan bahasa oleh masingmasing klaster.

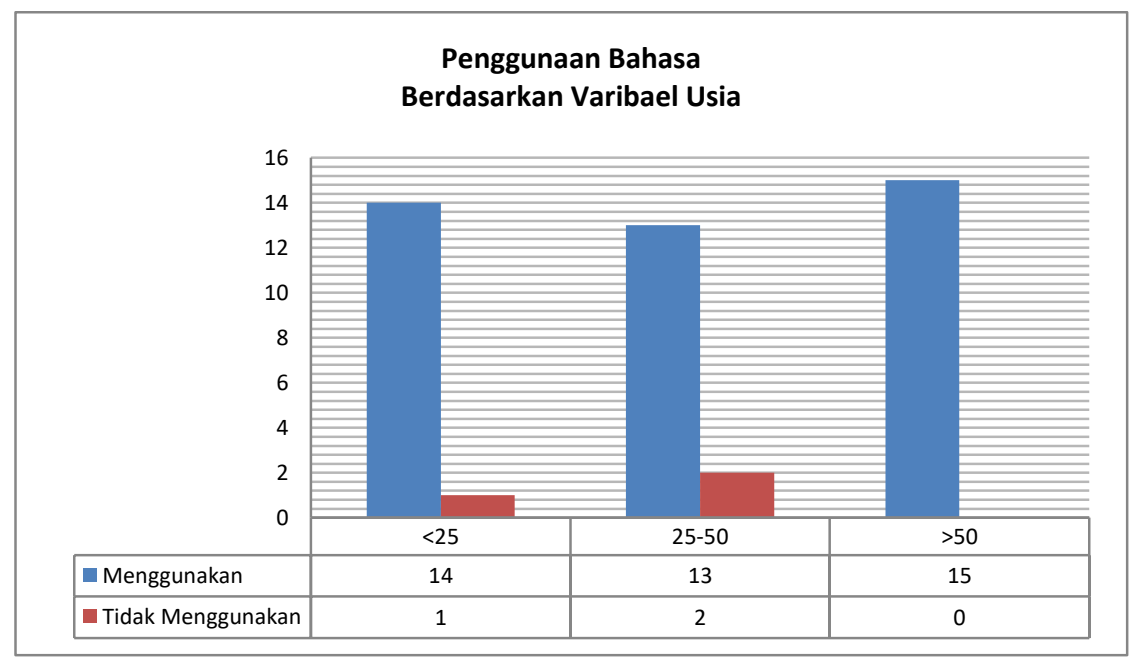

Halaman | 651 
Jurnal Onoma: Pendidikan, Bahasa dan Sastra PBSI FKIP Universitas Cokroaminoto Palopo Volume 6 Nomor 2
ISSN 2443-3667 (print)

ISSN 2715-4564 (online)

Hasil penelitian penggunaan bahasa berdasarkan usia responden menunjukkan tingginya tingkat penggunaan bahasa Dentong. Penggunaan bahasa Dentong pada penutur usia di bawah 25 tahun ditemukan sebanyak 14 orang yang masih menggunakan, dan sebanyak 1 orang yang tidak lagi menggunakan bahasa Dentong, sedangkan pada kelompok usia 25 sampai dengan 50 tahun ditemukan sebanyak 13 orang dan 2 orang yang tidak lagi menggunakannya, pada usia di atas 50 tahun keseluruhan responden masih menggunakan bahasa Denton. Hal ini menunjukkan bahwa persentase penggunaan bahasa Dentong pada seluruh klaster usia penutur masih tinggi.

Sama halnya dengan variabel usia penutur, variabel pendidikan responden juga tidak menunjukkan adanya pengaruh yang signifikan. Hasil penelitian menunjukkan seluruh klasifikasi pendidikan penutur masih menguasai dan menggunakan bahasa Denton sebagai bahasa utama dalam berinteraksi. Dari keseluruhan responden yang berjumlah 45 orang, kualifikasi pendidikan responden yakni SD sebanyak 17 orang, SMP sebanyak 8 orang, 13 orang SMA dan 7 orang berstatus 7 orang. Penggunaan bahasa Denton dari keseluruhan responden sebagai berikut;

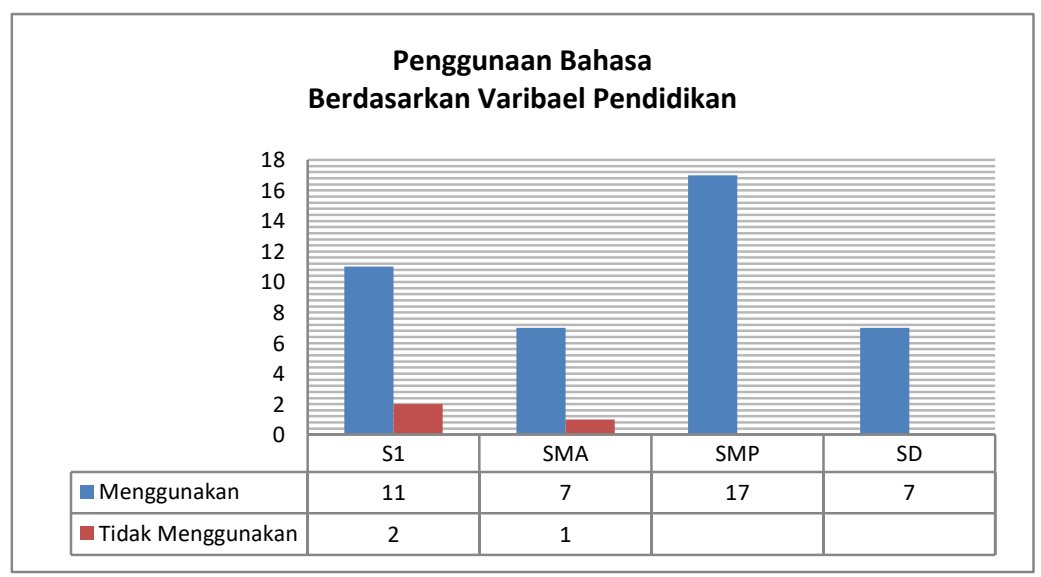

Hasil penelitian menunjukkan persentase penggunaan bahasa responden berdasarkan variabel usia masih tinggi. Klasifikasi pendidikan responden yang lulus sarjana sebanyak 13 orang dan 11 orang diantaranya masih menggunakan bahasa Denton, responden yang lulus SMA sebanyak 7 dari 8 orang yang masih menggunakan bahasa Denton. Sedangkan untuk kategori responden yang lulus SMP sebanyak 17 orang dan SD sebanyak 7 orang masing-masing masih menggunakan bahasa Dentong.

Selain mengkaji pemertahanan bahasa berdasarkan pertimbangan variabel sosial, penelitian ini juga fokus pada ranah penggunaan bahasa. Ranah penggunaan bahasa difokuskan pada ranah keluarga, tetangga, dan pemerintahan. Penelitian penggunaan bahasa Dentong pada setiap ranah penggunaan bahasa bertujuan untuk mengungkap seberapa sering responden menggunakan bahasa daerahnya dalam berinteraksi, dan melihat kecenderungan penggunaan bahasa lain sebagai alternatif penggunaan bahasa. Hasil penelitian tersaji sebagai berikut; 
Jurnal Onoma: Pendidikan, Bahasa dan Sastra PBSI FKIP Universitas Cokroaminoto Palopo Volume 6 Nomor 2
ISSN 2443-3667 (print)

ISSN 2715-4564 (online)

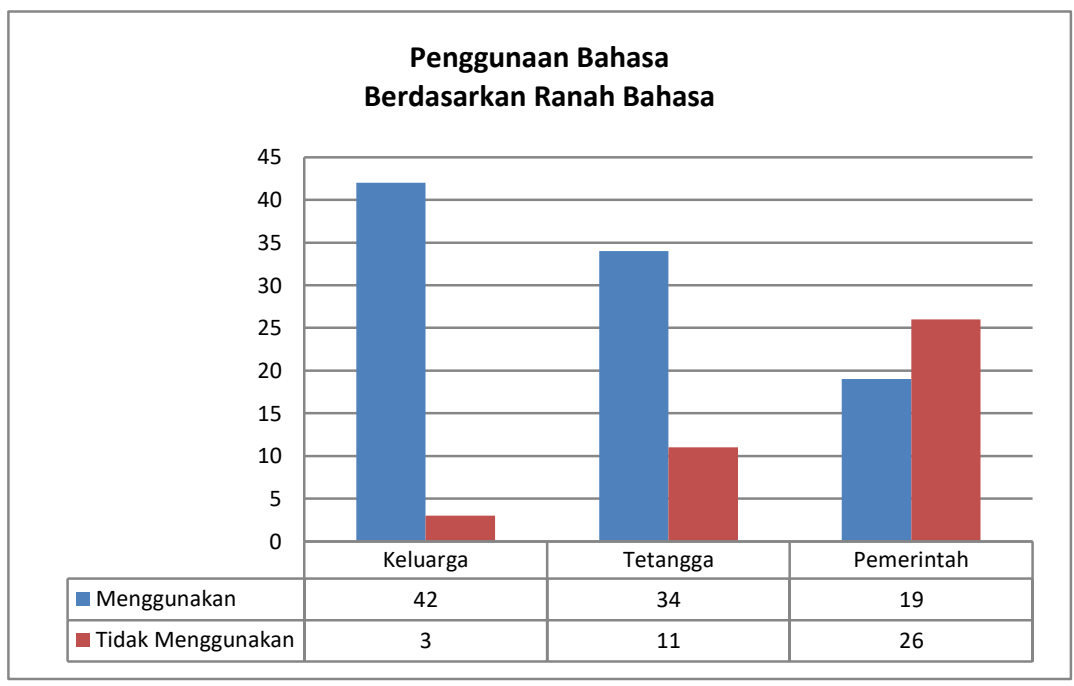

Hasil penelitian menunjukkan penggunaan bahasa pada setiap ranah memiliki perubahan prilaku penggunaan. Pada ranah keluarga menunjukkan penggunaan bahasa Dentong oleh responden sangat tinggi, hal ini ditunjukkan dari keseluruhan responden sebanyak 45 orang, hanya 3 orang responden yang tidak lagi menggunakan bahasa Dentong. Sedangkan pada ranah tetangga penggunaan bahasa Dentong dalam kategori cukup tinggi dengan jumlah penggunaan bahasa yakni sebanyak 34 orang dan 11 orang yang tidak lagi menggunakan bahasa Dentog pada ranah tersebut, hal yang berbanding terbalik dengan penggunaan bahasa pada ranah pemerintah, ditemukan sebanyak 26 orang dari jumlah keseluruhan responden yang tidak lagi menggunakan bahasa Dentong pada ranah pemerintahan. Hal ini menunjukkan bahwa semakin privasif ranah penggunaan bahasa, maka akan semakin sering responden menggunakan bahasa Dentong, sedangkan semakin formal ranah penggunaan bahasa, maka akan semakin responden menggunakan bahasa Indonesia sebagai pilihan utama. 
Jurnal Onoma: Pendidikan, Bahasa dan Sastra PBSI FKIP Universitas Cokroaminoto Palopo

Volume 6 Nomor 2
ISSN 2443-3667 (print)

ISSN 2715-4564 (online)

\section{Simpulan}

Berdasarkan pembahasan hasil penelitian yang ditemukan, maka dapat disimpulkan bahwa pemertahanan bahasa Dentong berada dalam kategori baik. Hal ini dapat ditunjukkan dari persentase penggunaan bahasa pada aspek usia berada dalam kategori yang tinggi, yakni dengan persentase penguasaan bahasa pada seluruh kelompok usia sebesar 93\% yang masih menggunakan bahasa Dentong. Tingginya persentase penggunaan pada setiap klaster usia utamanya pada kelompok usia produktif (di bawah 25 tahun) memproyeksikan tingkat kepunahan bahasa Dentong berada dalam kategori aman dari ancaman kepunahan bahasa, dengan asumsi bahwa dalam jarak 25 tahun ke depan, penutur usia produktif saat ini berpotensi besar dapat mewariskan bahasa daerahnya kepada keturunannya. Sedangkan berdasarkan ranah penggunaan bahasa, diperoleh hasil 93\% keluarga masih menggunakan bahasa Dentong sebagai pilihan utama dan $75 \%$ responden yang masih menggukan bahasa Dentong sebagai interaksi antar keluarga. Kondisi ini menunjukkan bahwa penggunaan bahasa Dentong sebagai alat interaksi utama baik dalam komunikasi intra keluarga, maupun antar keluarga. 
Jurnal Onoma: Pendidikan, Bahasa dan Sastra PBSI FKIP Universitas Cokroaminoto Palopo Volume 6 Nomor 2
ISSN 2443-3667 (print)

ISSN 2715-4564 (online)

\section{Daftar Pustaka}

Amir. (2009). Pola bahasa pada Ranah Keluarga di Kabupaten Pangkajene Kepulauan. Dalam Disertasi, Makassar; Program Pasca Sarjana Universitas Hasanuddin.

Anderson, T. David. (2010). Pelestarian dan Pengembangan Bahasa Moronene. Dalam Makalah Seminar Internasional Bahasa-bahasa Daerah Sulawesi Tenggara pada tanggal 18-21 Juli 2010 di Buton.

Budhiono, R. Hery. (2019). Pergeseran dan Pemertahanan Bahasa Jawa di Daerah Transmigrasi di Kota Palangkaraya. Aksara, 31 (2), 285-298.

Chaer, Abul dan Agustina. (2010). Sosiolinguistik: Perkenalan Awal. Jakarta: PT. Rineka Cipta.

Emzir. (2016). Metode Penelitian Kualitatif: Analisis Data. Jakarta: PT. Raja Grafindo Persada.

Ibrahim, Gufran Ali. (2011). Bahasa Terancam Punah: Fakta, Sebab-Musabab, Gejala, dan Strategi Perawatannya. Masyarakat Linguistik Indonesia, 29 (1), 35-52.

Lukman dan Gusnawaty. (2013). Ancangan Model Pembinaan, Pengembangan, dan Pelestarian Bahasa. Makassar: Universitas Hasanuddin.

Nasrullah, Ince. (2016). Penggunaan Bahasa Dentong pada Suku Bugis dan Makassar di Kecamatan Cenrana Kabupaten Maros. Ecosystem, 16 (1), 1-8.

Sahril. (2018). Pergeseran Bahasa Daerah pada Anak-Anak di Kuala Tanjung Sumatra Utara. Ranah, 7 (2), 210-228.

Sumarsono dan Paina Partana. (2004). Sosiolinguistik. Yogyakarta: Sabda. 